taxonomy of ostracods. Four recent publications have in part met this need.

The first to appear was a comprehensive text-book on micropalæontology by Pokorný, dealing extensively with ostracods, but including also Foraminifera and other microfossils. This has boen published in German (1958), and an English translation is shortly to appear. The second (in Russian) is the ostracod section of the comprehensive Osnovii (1960). The third is volume $Q$ of the Treatise on Invertebrate Paleontology (1960) and the fourth the magnificent two-volume handbook by van Morkhoven, Post-Palaeozoic Ostracoda.

By restricting his attention to the post-Palæozoic ostracods, van Morkhoven has been able to deal with his material much more extensively than have his rivals. Moreover, the work itself occupies some 680 pages, compared with 442 in the Treatise, 158 in the Osnovii, and 257 by Pokorný. As in many parts of the world, postPalrozoic systems are the only part of the geological column of interest to those exploring for oil, the omission of any consideration of Palæozoic forms is not so serious as it might at first sight seem. It is, however, pertinent to remomber that ostracods are no less common in Palæozoic rocks than they are in the post-Palæozoic, nor are they less varied, or less valuable as stratigraphical indices. Moreover, many morphological features were developed in Palæozoic forms which are not found in the post-Palæozoic.

Be that as it may, van Morkhoven's work provides quite the most satisfactory and most comprehensive treatment available. Moreover, it is much more than a mere summary of other people's work. Chapter after chapter is packed with original observations which at once establish van Morkhoven as a leader among research workers in this field. Many of his own original illustrations show how well he has profited from his contact with the doyen of fossil ostracod workers, Dr. Erich Triebel. He very properly draws freely on Triebol's own published work, and even includes (with acknowledgements) some of his unpublished observations. For English-speaking readers, this will provide a ready source for a great volume of outstanding research previously only available in the German.

The first volume (the slimmer of the two) deals with general questions, including the morphology of both hard. and soft parts, the terminology, ecology, life-history, stratigraphical occurrence and the techniques of collection, preparation and study. Technical terms are listed in dictionary form in English, German, French, Italian and Russian. There is also a useful ehapter on the taxonomy of supra-generic groups, though this chapter unfortunately suffers from a drawback -a drawback that, to a lesser extent, also reduces the value of some of the other chapters; for although Volume 1 was not published until late in 1962, and Volume 2 not until 1963, the manuscripts were completed many years before, and Volume 1 has not been revised since 1958, nor Volume 2 since 1959. As a consequence, van Morkhoven was unable to consult Pokorny's work, the Russian Osnovii or the Treatise. This would not have mattered if his own work had been published earlier, as then at least the Treatise could (to its own great advantage) have made reference to it. But, as it is, van Morkhoven's taxonomy, nomenclature and terminology are, in some respects, out of date.

Volume 2 is more than twice the size of Volume 1, and consists entirely of generic descriptions. Like Volume 1, it is extensively illustrated, and contains much previously unpublished information. It does not deal at all with the recognition of species, but will be quite indispensable to all those faced with the task of elassifying post-Palæozoic material. This is the sort of practical handbook that will be on every micropalæontologist's shelf, but which will need constant supplementation to retain its usefulness, and it is much to be hoped that the author and his publishers will devise a method of producing such supplementis.

\section{GEOMORPHOLOGY OF SOUTH AFRICA}

\section{South African Scenery}

A Textbook of Geomorphology. By Dr. Lester C. King. Third edition-revised. Pp. $\mathrm{xxv}+308+168$ plates. (Edinburgh and London: Oliver and Boyd, Ltd., 1963.) $50 s$.

7 HE third edition of Prof. King's well-known textbook differs from the previous editions mainly in having been "considerably curtailed to make it handier than its predecessor". The shortening has been accomplished by the elimination of sixty pages of print, sixteen text figures, no less than ninety-eight plates, and the folding, colour-printed "Frosion-Cycle Map of Central and Southern Africa" that constituted a novel and stimulating feature of the second edition published in 1951. These modifications have effected a notable improvement, particularly with regard to the general tightening up of the text and the elimination of unnecessary illustrations. At the same time, one regrets to seo the erosion-cycle map go, and it is questionable whether a comparatively small saving in page space was justified at the expense of all lists of reading references at the ends of chapters. As the book now stands it possesses no bibliography at all.

The loss of close to a hundred plates might appear to have changed its character entirely, but this is by no means the ease, as 168 plates still remain, and the volume retains its position as one of tho best illustrated of its type.

The main title is, perhaps, slightly misleading and fails to convey to the now reader that the book is, in fact, a comprehensive and very excellent genoral text-book of geomorphology in which, admittedly, the illustrative examples are drawn mainly from Africa, and predominantly from Southern Africa. There is, howover, considerable justification for this, having regard to the varied lithologies, geological structures and geomorphological environments displayed, to say nothing of the prolonged period of continental history to which the region has been subjected; sufficiently long to have outlasted many geomorphological cycles.

It is very natural that any text-book of this type from the pen of Prof. King, based largely on African examples. will emphasize the outlook of Penck rather than that of Davis. The evolution of hill-slopes is consequently seen as equally important as, if not more than, the evolution of river valloys in the development of landscape, and pediplanation replaces peneplanation as the major factor in the formation of erosion surfaces. The 'normal cycle of erosion' finds no mention, a fact that is scarcely surprising to anyone familiar with the geomorphological conditions in Central and Southern Africa, where there is little to support the basic idea, but instead one finds a lucid diseussion of the hill-slope and pediplanation cycles.

In addition to a systematic treatment of the various standard geomorphological environments, four chapters are devoted to the topographical effects of land movement. These sections are particularly valuable and serve to emphasize the significance of geomorphological analysis as an important branch of structural geology. The final chapters, comprising some eighty-five pages, are devoted to a consideration of the geomorphology of the African territories, including Central, Southern and East Africa, and apply the basic principles of analysis to the regions concerned.

The book covers the entire field of geomorphology and, at the same time, presents a refreshingly different approach to the subject. It would well repay reading by all geologists and those physical geographers who are concerned particularly with the structural significance of landscape.

W. Q. KenNeDY 